\title{
Priorities, policies and practice of e-government in a developing country context: ICT infrastructure and diffusion in Jamaica
}

\author{
David H. Brown ${ }^{1 \dagger}$ and \\ Sheryl Thompson ${ }^{1 \dagger}$
}

${ }^{7}$ Department of Management Science, Lancaster University Management School, Lancaster, U.K.

Correspondence: David H. Brown, Department of Management Science, Lancaster University Management School, Lancaster LA1 4YX, U.K.

Tel: + 44 (0) 1524594206
$\Varangle$ Both authors contributed equally to this paper

Received: 13 September 2008 Revised: 17 June 2009

2nd Revision: 10 October 2009

3rd Revision: 20 December 2009

4th Revision: 9 November 2010

5th Revision: 3 January 2011

Accepted: 13 January 2011

\begin{abstract}
This paper presents the findings of recent research into e-government policies and initiatives undertaken by the Government of Jamaica within the context of selective intervention facilitated through financial and technical assistance. In the specific context of a developing economy it highlights the use of infrastructure building and government intervention to aid diffusion of information and communication technology (ICT) and draws attention to the differences between developed and developing countries in their approach to e-government. A case of the Jamaica Customs Department is provided to exemplify the implementation of e-government in practice. Using institutional factor analysis for IT innovation the interaction of policy and practice is analysed. Four significant themes are identified that characterise the context for e-government policy, together with the associated institutional factors. The relative importance of these factors is demonstrated with Innovation Directive, Standards and Subsidy shown to be prime. These findings contribute to both institutional factor analysis for IT innovation and to ICT adoption theory, and together signal the importance of the inclusion of policy-based intervention in a future research agenda for e-government in a developing country context.

European Journal of Information Systems (2011) 20, 329-342. doi: $10.1057 /$ ejis.20I I.3
\end{abstract}

Keywords: electronic government; transformational government; developing economies; government intervention; supply-push and market-pull; institutional approach

\section{Introduction}

The purpose of this paper is to report recent research on the priorities, policies and practice of e-government in Jamaica. Like other developing countries its needs and experiences differ from developed economies and it is this difference that has implications for theory and practice. In theory there is a wide imbalance in extant research between developed and developing countries, and in particular an understanding of the contexts within which information and communication technology (ICT) are being introduced. In practice the issues in developing countries are dominated by inadequate financial and human resources and a dependency on external institutions. In this context the national policy priorities for ICT, such as infrastructure developments and mechanisms for their implementation, are prime and are the setting for this paper.

The background to e-government, and especially transformational government (t-government), lies in the wider debate about technology and its contribution to social, economic and political processes. The proliferation of the Internet into most aspects of society and commerce has propelled ICT to the forefront of innovation and organisational change. Its 
ubiquitous nature and the varied opportunities it presents are potentially beneficial to governments, organisations and citizens. It is not surprising, therefore, that following the early IT and competitive advantage literature ICT was proposed as a catalyst for change within public and private sector organisations and institutions in the 1990s (King \& Kraemer, 1995). It is against this background that the modernisation of public sector entities through the use of ICT, especially Internet and web technologies, has been a focal point during the last decade (e.g. Heeks, 1999; Fountain, 2001).

The notion that governments can utilise digital technologies to provide improved services to citizens, businesses and other stakeholders through better access, transparency and coordination of information and services is one that is deep seated, indeed it has taken on mythological status (Bekkers \& Homburg, 2007). It is underpinned by the belief that such a transformation will yield economic efficiencies and more effective governance. In the U.K. and other developed countries the historic emphasis has been on the citizen. The availability of websites for all government departments and the opportunity for citizens to engage with government, both national and local, has been the starting point for the policy of citizen-centric public services (King \& Cotterill, 2007).

In contrast for developing countries the starting point has been different. For these countries it is highly likely that any progress in e-government will be wholly or partially funded through aid programmes of the World Bank or related development agencies. Such financial assistance is required to meet specific criteria hence the World Bank's definition of e-government is central, and gives an insight into the priorities:

E-Government refers to the use by government agencies of information technologies (such as Wide Area Networks, the Internet, and mobile computing) that have the ability to transform relations with citizens, business, and other arms of government ... the resulting benefits can be less corruption, increased transparency, greater convenience, revenue growth, and/or cost reductions. (The World Bank, 2007a)

In the Bank's definition the aims are broad and in particular the inclusion of economic growth as a goal is completely consistent with previous policy guidelines on ICT within the context of a digital divide. For developing countries the strategic imperative is economic development. It is only through this that meaningful Internet access by citizens and businesses can be achieved. The aim of ICT enhanced public administration and governance while desirable is necessarily secondary. For developing countries, therefore, the egovernment era means the implementation of policies and programmes to aid ICT diffusion and to encourage ICT uptake and use, with far-reaching impacts on businesses and citizens. It is indivisible from economic development.
At the turn of the decade the Jamaican Government mandated ICT as an integral part of its plans for economic development. Utilising data collected through document analysis and interviews with personnel in key government institutions, managers of private companies and other stakeholders, this paper traces this recent history of e-government policy and initiatives in Jamaica. A case study is used to illustrate Government intervention as a mechanism for diffusion. The aim, as indicated in the opening paragraph, is to add to and reflect on the realities of e-government implementation in a developing economy.

The paper is structured as follows. In the next section selected relevant literature in respect of the changing scope of e-government and the developing country dimension is introduced followed by a concise description of the research approach. The subsequent section maps the ICT landscape in Jamaica within the ambit of the national strategic plan for ICT. In the later section e-government initiatives are identified and their impact examined through the case of the Jamaica Customs Department. In the penultimate section the findings from the previous two sections are analysed and discussed. Finally in the last section conclusions for future research are drawn.

\section{Selected literature}

The literature on e-government is problematic. On the one hand there is a growing but relatively scant literature on developing countries, on the other a burgeoning of empirically based contributions from the developed world. New public management (NPM) and public sector reform based on deregulation, privatisation and marketisation (DPM) are the dominant intellectual frameworks within which ICT initiatives are justified and rationalised (examples include: Lane, 1997; Bellamy \& Taylor, 1998; Avgerou et al., 2005). It is beyond the scope of this paper to review these and other contributions in depth. Rather, focus is given to three aspects - firstly, the trajectory and perception of e-government since this perception influences the filter through which actual e-government developments are typically viewed; secondly, a discussion of selected developing country contributions; and finally, consideration of an institutional perspective as a means of exploring e-government diffusion. Each is discussed below.

\section{Perspectives on e-government and transformation}

Within this literature primacy is given to contributions which critically inform the perceptions of e-government including the political and societal expectations. It is these perceptions that influence policy not only in the developed world but, as the World Bank definition highlights, also the developing nations.

In her authoritative and influential recent review of e-government in Britain from 1995 to 2005 (defined as 'the use by government of information technology internally and to interact with citizens, businesses and 
other governments'), Helen Margetts (2006, p. 263) reports annual spending of about $£ 14$ billion on e-government. This is a huge commitment but her conclusions regarding outcomes are mixed. Compared to other major developed economies the e-government project failure rate in Britain is high and citizen participation low. Despite this disappointing outcome the commitment to e-government and its transformational potential remains undimmed (e.g. Minister for Cabinet Office, 2005). The reasons for this are embedded within the trajectory of e-government as a concept. From early arguments that the modernisation of public administration depends on the effective exploitation of new information flows in government (Bellamy \& Taylor, 1998) to current observations on t-government in local authorities (e.g. King \& Cotterill, 2007; Dhillon et al., 2008), the belief that e-government delivers better and more efficient governance is widely accepted. This includes highly influential international institutions such as the OECD (OECD, 2003, 2005, 2008). A convincing analysis of these myths or beliefs and their impact on the e-government agenda is provided by Bekkers \& Homburg (2007).

Although the proponents of transformation provide arguments and evidence of achievement (e.g. O'Donnell et al., 2003; Beynon-Davies \& Martin, 2004; Irani et al., 2008), there are counter views. Cordella (2007) suggests that the transformation intent may be misguided and that e-government policies themselves may need to support aspects of existing bureaucratic systems, rather than see ICTs being utilised in order to dramatically reorganise and transform public administration. In a similar vein many other authors have pointed to the difficulties of realising radical change rooted in the inherent incrementalism of organisations, political constraints and competing institutional arrangements (e.g. West, 2004; Norris \& Moon, 2005; Barca \& Cordella, 2006; Dhillon et al., 2008). Such views, however, contrast with the World Bank's view that explicitly promotes transformational change in the developing country context.

\section{Developing countries}

In the context of this paper three main overlapping issues frame the discussion of e-government in developing countries and guide the selection of literature: the scope and policy of e-government; e-government readiness; and the role and responsibility of government in the diffusion of ICT-based innovations. The starting point for policy is the recognition that the digital divide between developed and developing countries is deeply embedded and closely correlated to GDP (e.g. Gibbs et al., 2002). The most recent World Development Reports shows that a person from a high-income country is over 22 times more likely to be an Internet user than a lowincome country; this is significant as $37 \%$ of the world's population lives in low-income countries. Other measures such as secure Internet servers, mobile phone penetration and land line usage exhibit similar or even larger differentials, and ICT is often nonexistent in rural populations. In the case of least developed nations the divide is yet larger with access 10 times less than developing countries (UNCTAD, 2005; World Bank, 2007b).

Against this background the World Summit on the Information Society under the Tunis Agenda explicitly laid out the need for ICT plans as an integral part of developing countries' national development plans (WSIS, 2005). The core e-government policy themes of accessibility, engagement, accountability and economic development form the basis of The e-Government Handbook for Developing Countries (Centre for Democracy and Technology, 2002). This experientially based guide provides country examples and highlights the key challenges for e-government, including cost effectiveness in areas such as public procurement, tax collections and customs operations, and better contacts with citizens especially those in remote areas. Other international institutions have also contributed to the policy debate including UNCTAD's influential Information Economy Report (2006), OECD's E-Commerce and Development Report (2004) and the United Nations Public Administration Network surveys (UNPAN, 2003, 2004, 2005, 2008). In all of these a recurring theme is the interaction of technical, financial, social and managerial factors in delivering transformation through e-government. In developing countries this task is made further difficult by the inadequacy of resources and dependence on financial intermediaries. This key point has been recognised by many of the international agencies, including the World Bank:

\footnotetext{
Bilateral and multilateral assistance will continue to play a significant role in the building framework conditions for IT development. International financial institutions are well placed to contribute in this regard by formulating and implementing programs that foster growth, benefit the poor, as well as expand connectivity, access and training. (World Bank, 2001, p. 2)
}

The second issue, and closely linked to that of policy, is the state of 'e-readiness', defined as 'a country's ability to take advantage of the internet as an engine of growth and human development' (Rahman, 2007, p. 226). Designing methodologies and measuring e-readiness has been a key activity (e.g. Bui et al., 2003; Banerjee \& Chau, 2004; EIU, 2005; Kovacic, 2005; World Bank, 2005; Rahman, 2007; UNPAN, 2008). Both macro and micro measures have been considered but key elements include infrastructure, telecommunications, Internet connections and human skills. These measures are frequently manifested as expressions of the 'digital-divide'. The divide, however, is not restricted to individual access but is also reflected between large and small firms (Brown $\&$ Lockett, 2004) and in non-technology-related areas such as income and education. Clearly, there is no sense 
in governments creating online services that cannot be utilised by users, citizens and businesses due to lack of access attributed to prohibitive costs or poor infrastructure. This underlines the importance in developing economies of ICT infrastructure as a pre-condition for electronic delivery of e-government services, a point emphasised by Schware \& Deane (2003). Since 2000 e-readiness has been monitored by the U.K.'s Economic Intelligence Unit using a six-criteria classification including technology infrastructure and government policy and vision. The developing countries remain firmly at the bottom. In 2008 the top 17 of 20 countries in the technology connectivity category were also the highest users; the reverse was the case for low connectivity countries. Confirmation that infrastructure and participation are very highly correlated (EIU, 2009).

The third and final issue relates to the role of government in diffusion. The issue of government intervention vs non-intervention as a policy imperative in the diffusion of technologies is part of a wider debate, but in the main 'selected intervention' has emerged as a viable option (World Bank, 2005; Altenburg \& von Drachenfels, 2006). In the context of developing economies and e-government the first three major challenges identified by the World Bank's Centre for Democracy and Technology - infrastructure development, law and public policy, and the digital divide - are all areas in which government leadership and resources are required. Despite this imperative the lack of success in ICT-based projects in developing economies is a dominant theme (Avgerou \& Walsham, 2001; Heeks, 2002). As Heeks points out failure occurred in many of these projects despite the government's role as a major stakeholder. A further complication is that most e-government implementations in developing countries have been based on developed countries' experiences (Huang et al., 2002). The importance, therefore, of effective policy for ICT diffusion to reduce the risk of failure has long been recognised (e.g. Gilbert, 1992; King et al., 1994; Damsguarard \& Lyytinen 1996; Montontealegre, 1999).

Following on from the above is recognition that classical new technology diffusion theory (e.g. Rogers, 1983, 1995), arising from an organic process subject to market push-pull mechanisms, is not sufficient. Both firm-level factors and provider issues hinder diffusion. Technology transfer in contrast occurs through purposeful policy, planning and innovation and is provided through a different set of environmental influences. The distinction between the two is not always appreciated by authors - an observation made by Baskerville \& Pries-Heje (2003).

\section{Institutional perspectives}

The importance of considering organisations and their environmental context together is central to an institutional perspective. Pioneered by Selznick (1957) it has led to an important strand of contemporary sociological thought on social action including organisational change. From Selznik's early views of organisations as relatively fixed organisational forms - technical or institutional - with the former being engineered and the latter the product of environmental interaction and adaptation, to current views of formal organisations as instantiations of institutional arrangements whose operations are underpinned by 'complex and historically cumulated systems of rules, laws and regulations' (Kallinikos, 2006, p. 116), an institutional approach has proved to be valuable means of understanding the socially constructed evolving logics that give meaning to organisational actions (Friedland \& Alford, 1991). This includes the propensity of organisations to resemble each other in response to their institutional setting (Meyer \& Rowan, 1977). This concept of institutional isomorphism was further developed by DiMaggio \& Powell (1983) to embrace the notions of coercive, mimetic and normative isomorphism to explain this convergence of organisational behaviours. In the specific context of the adoption of ICT, Avgerou (2000) reinforces this potential of institutional theory to offer a powerful insight into how ICT is implicated in organisational change.

In a complementary strand of thinking to the above, King et al. (1994) in an influential article explored institutional factors in the context of policy formulation for IT innovation. The authors point to the lack of coherent advice for creating government policy that signals a lack of understanding of the role of government institutions. According to the King et al. model, there are six types of actions: knowledge building, knowledge deployment, subsidy, mobilisation, standard setting and innovation directives, that institutions can perform in an influential or regulatory role to produce the 'supply (technology)-push' or 'demand (need)-pull' context for the actions to be effective. Influential intervention is where the institutions use their powers, without being forceful, to affect attitudinal and behavioural changes from those governed. On the other hand, regulatory interventions are direct and forceful in nature where standards and rules are enforced (Henriksen \& Andersen, 2004).

In reality many countries will adopt a mixed model. China is an example and Chen et al. (2006), using a framework developed by Huang et al. (2002), characterises China's policy as government-driven with private sector partnerships. However, even within this approach a government supply-driven programme of network rollout underlines the essential importance given to infrastructure development.

In Jamaica, there is strong evidence of both kinds of intervention - supply-push and demand pull. Some of these intervention policies, their impact on infrastructure building and the enabling of diffusion are highlighted later in the paper. In the next section the research method is outlined. 


\section{Method}

The research concern at the heart of this paper was to better understand the links between the priorities, policies and practice of e-government in a developing country (Jamaica), as a means of providing wider insight into the importance of context for researching e-government. This was a complex or 'soft' concern (Checkland \& Poulter, 2006) where the issues were interpretative and required an empirical method that allowed the researchers to explore experience, understanding and meanings in depth (Silverman, 2005). This argued strongly for an overall qualitative approach using both secondary sources (official Government of Jamaica (GOJ) documents) and primary sources (semi-structured interviews). The research focus itself necessitated two separate strands of investigation. The first was to explore the priorities and policies for e-government at a Government level; the second was to appreciate evidence of e-government in practice. Each is discussed below.

\section{Investigation strand 1: policy and priorities}

The first strand of investigation was the identification, tracking and interpretation of relevant policy initiatives to provide the context within which subsequent implementations could be framed. This was done initially through archival analysis from publically available GOJ reports from 1996 to 2008. The initial quality of the documents was assessed using the criteria of authenticity, credibility and meaning (Scott, 1990). The analysis started with the National Industrial Policy (NIP), which laid out a comprehensive approach to industrial and economic development, specifically identifying the integration between macro, industrial, social and environment policies as critical to increasing productivity in selected sectors. In the implementation of this policy ICT was elevated to the role of catalyst or 'driver' for increased growth. In 2000 the NIP led directly to the Jamaican National Strategic Plan for IT and in parallel to the creation of implementing agencies and a raft of implementing instruments. In each case the analysis of this archive sought to identify policy intent triangulated against the budget allocations and specific named initiatives. The process involved identifying in each document the intent, scope, stakeholders, timescale and implementation plans of the policy or the policy initiative. Related policy documents were compared for consistency and budget details used to assess the feasibility of the implementation plans, or the progress made for initiatives underway.

To complement and reinforce this analysis interviews with all the key stakeholders in the government, aid agencies and trade associations were held, a total of 17 interviews. The number of interviewees constituted all the internal and external stakeholders at Minister, Director and Deputy Director level and senior managers. It included the Minister of Commerce, Science and Technology and the Director of E-Government initiatives. Staffs below these levels were not involved in the formulation of ICT policy or policy evaluation. The interviews were semi-structured and, subject to permission (60\% agreed), were tape recorded. Contemporaneous notes were taken as necessary. The aim was to understand the context within which participants act, their sense making and the process by which events and actions took place set against the declared policies identified above in the document analysis (Maxwell, 1996). Critical to the integrity of the qualitative interviewing was the objectivity of the researchers. One of the authors was previously a GOJ employee in the ICT field. This was helpful but needed care to avoid bias. It was tackled through adopting Jennifer Mason's meticulous approach to qualitative interviewing that incorporates an active form of reflexive practice around key issues (Mason, 2002). A research diary and efficient record keeping allowed the research journey to be tracked and revisited.

\section{Investigation strand 2: e-government practice}

The second strand of investigation was to appreciate policy in practice. Since e-government in Jamaica is recent, the research design requirement was to access an early GOJ-implemented e-government initiative. These were few and the most complete was the Jamaican Customs Automated Services (CASE) initiative. This offered the greatest opportunity for reflection and suggested that a case study would be appropriate and would allow the interaction of the phenomena and its context to be explored in a deep and challenging way (Yin, 2003). Flyvbjerg puts it another way - the advantage of the case study is that it can 'close in on real-life situations and test views directly in relation to phenomena as they unfold in practice' (Flyvberg, 2006, p. 235). Such an approach was essential in this research since the interaction between policy context and the reality of implementation was central.

The case study was crafted from the qualitative interviews with the government and external stakeholders, including brokers. These were complemented by additional interviews within the customs department. The interview protocol in the case study was the same as for the policy analyses and used tape recorded interviews of typically one to two hours, and guided by Mason's approach introduced earlier.

The subsequent analysis of the transcripts, and of the written accounts of the non-recorded interviews, for both strands 1 and 2 of the investigation was manual. The decision not to use computer-assisted qualitative data analysis (CAQDAS) was taken on the grounds of the relatively low volume of transcripts, the mix of transcripts and interviewer accounts and the nature of the material. The analysis was undertaken in three stages. Firstly, given the broad policy-based nature of the interview material, care was taken not to decontextualise the material by coding text into chunks and retrieving this later without the context. For each interview the main topics and issues that emerged were noted 
together with their context. Stage two used the six institutional factors as identifying nodes (similar to the NVivo CAQDAS protocol) to review the texts for evidence of their relevance. Often sub-nodes were required. For example, the institutional factor 'Subsidy' occurred in the interview narratives as direct financial aid, technical assistance, matched funding and programmes funding. Stage three revisited stages one and two to rationalise the analysis and eliminate overlaps. The outcome was the identification of four themes from the stage one analysis each explained in terms of the associated institutional factors.

Finally, in terms of the overall justification for the qualitative, case-based approach, it is important to stress that in terms of the research findings the aim was not to seek generalisation. In an emerging field, such as understanding the links between policy, infrastructure and e-government implementation in developing and transitional economies, a representative sample country or countries is meaningless. The requirement is for exemplars that strengthen and lead to a better understanding of the issues and their interaction, and hence contribute to theory development.

In summary, to research the core concern of this paper, namely the interaction between the policies and practice of e-government in a developing country, the research method combined two strands of empirical investigation. The first was to appreciate e-government policy and priorities - in brief the changing ICT landscape in Jamaica; the second was to examine a specific e-government policy initiative - in this case the CASE, and to track its diffusion, implementation and outcome. Both strands are introduced in the next two sections. Overall, the combined approach was phenomenological, inductive and interpretive.

\section{Policies and priorities - a changing ICT landscape} In this section the findings from the first empirical strand relating to the priorities and policies of e-government are introduced. Jamaica's early priorities were twofold: (i) building infrastructure and (ii) building knowledge and capability in the ICT sector. Together these constitute the antecedents for practice.

\section{Building infrastructure}

Facilitating improvement and growth in telecommunications infrastructure - technical, legal and regulatory - is an essential antecedent for ICT diffusion (Odera \& Madon, 1993; Hanna, 2003; Schware \& Deane, 2003; UNCTAD, 2006). The last 10 years have seen significant changes in the ICT landscape in Jamaica. In 2000 the GOJ presented its five-year strategic plan for IT. It projected that the ICT sector would become a major source of job creation over the life of the plan. The integration and development of ICT into the Jamaican economy was a strategic imperative with the explicit aim of economic advancement. The vision was to use ICT to create an enabling environment for the evolution of other sectors in the economy. The formal and published strategic plan for ICT focused on four key objectives (GOJ, 2002):

- infrastructure and access - creating a competitively priced nationwide public information and communication technologies network;

- e-government - using information and communication technologies to provide efficient government services to the public;

- economic development - using the Internet to facilitate growth in international trade;

- e-business - promoting the development of electronically transacted business.

These objectives would be achieved by setting short- and long-term goals geared towards improving telecommunications infrastructure and regulations, and by policy implementation through initiatives. Established as an independent organisation the Central Information Technology Office took ownership of the strategic plan for ICT and its main roles were to coordinate the implementation of the ICT plan by providing recommendations about appropriate policies, and build partnerships between local and overseas public and private sector organisations.

Developing countries have been routinely encouraged to deregulate and liberalise telecommunications in a bid to increase competition, and hopefully drive down the cost of access to individuals and businesses. A new Telecommunications Act was passed by the GOJ in 2000 and led to a phased liberalisation of the telecommunications industry over a three-year period. A key aim was to expand the deployment of broadband technology, which in turn was seen as crucial to the successful implementation of e-government.

In addition to new telecommunications policies, the Jamaican Government took steps to improve its legislative and regulatory framework for new economy practices. An Electronic Transactions Policy was drafted in 2003 and passed as an Act in 2006 (GOJ, 2003). In the regulatory arena, the Spectrum Management Authority was established in 2001 with the responsibility of managing the radio spectrum of Jamaica, while the Office of Utilities Regulations and the Fair Trading Commission increased their focus as regulators in the telecommunications industry.

\section{Knowledge building through intervention}

The second priority of Jamaica's IT policy was centred on knowledge building and deployment in the ICT sector. Within the public sector a prominent example of knowledge building in Jamaica involved the development of the Fiscal Services Limited (FSL) to provide software solutions for e-government initiatives. FSL is the government agency that works for government clients, and has been responsible for engineering electronic linkages among public sector organisations with custom developed software. Through FSL knowledge building is being 
supported and in this sense the learning is accumulative and can be shared within Jamaica. This organisation has been crucial to the integrated approach to e-government implementation. Although an independent GOJ agency its work was and remains frequently embedded within international aid funded programmes, such as the Public Sector Modernisation Program (PSMP).

Complementary and essential to this policy to build Jamaican ICT capacity and encourage the diffusion of ICT is a well-trained population. The national strategic ICT plan has informed the national education policy. The Jamaican Universal Service Fund was started in 2005 with the collection of tariffs on telecommunications terminating in the Island (GOJ, 2006). The fund is earmarked to finance the e-Learning Project to ensure the availability of Internet access in schools, and also through libraries and Post Offices that serve as community access points.

\section{E-government in practice}

Following on from the discussion of the joint antecedents of building infrastructure and knowledge in the ICT sector, the second strand of investigation was to appreciate ICT policy in practice. Under the national strategic plan for IT the GOJ commits to provide its citizens and businesses with efficient government services through the use of ICT (GOJ, 2002). The government views its own use of technology as critical to the diffusion and adoption of Internet technologies by both businesses and individuals, and aims to become a model user of these technologies. The PSMP is funded by the GOJ and international agencies (PIOJ, 2005, 2006). These include the World Bank, the European Union (EU), the Canadian Internal Development Agency, the Department for International Development in the United Kingdom and the Inter-American Development Bank (IDB). PSMP encompasses approximately 30 current projects geared at public sector reform, through e-government-related initiatives.
Strategically, the Government earmarked as priorities those ministries and agencies that were revenue generating and facilitated international trade.

To achieve this GOJ established key partnerships between the public and private sector to facilitate the implementation of e-government. One such partnership was the Jamaica Trade Point (JTP), an electronic portal that enables interaction between government and stakeholders in the Import/Export sector. Via this portal the business community can access services and link to other sectors such as transportation, banking and business support providers. The aim is to provide seamless trading facilities. Figure 1 displays the interaction of the JTP with key government agencies already providing online services.

The pursuit of e-government initiatives has followed a coordinated approach with various agencies harmonising their goals under the umbrella of one project, as exemplified by the JTP Project. Within this umbrella project an early initiative was the Jamaica CASE. This project is introduced below in the form of a case description to illustrate the policy implementation process. The analysis and interpretation of this case, together with the findings from the earlier policy and prioritisation section, are discussed in the analysis and discussion section which follows the case description.

\section{The case of the Jamaica Customs Department Automated Clearing Initiative}

The setting of standards can be used for diffusion of an innovation by making its use mandatory. King et al. (1994) suggested that standard setting could be used in the regulation of decentralised actors and organisations to bring them in line with larger social or institutional objectives. Interventions of this nature can involve the establishment of standards under which innovative activity might be encouraged, requiring that particular products or processes are to be used in any work for

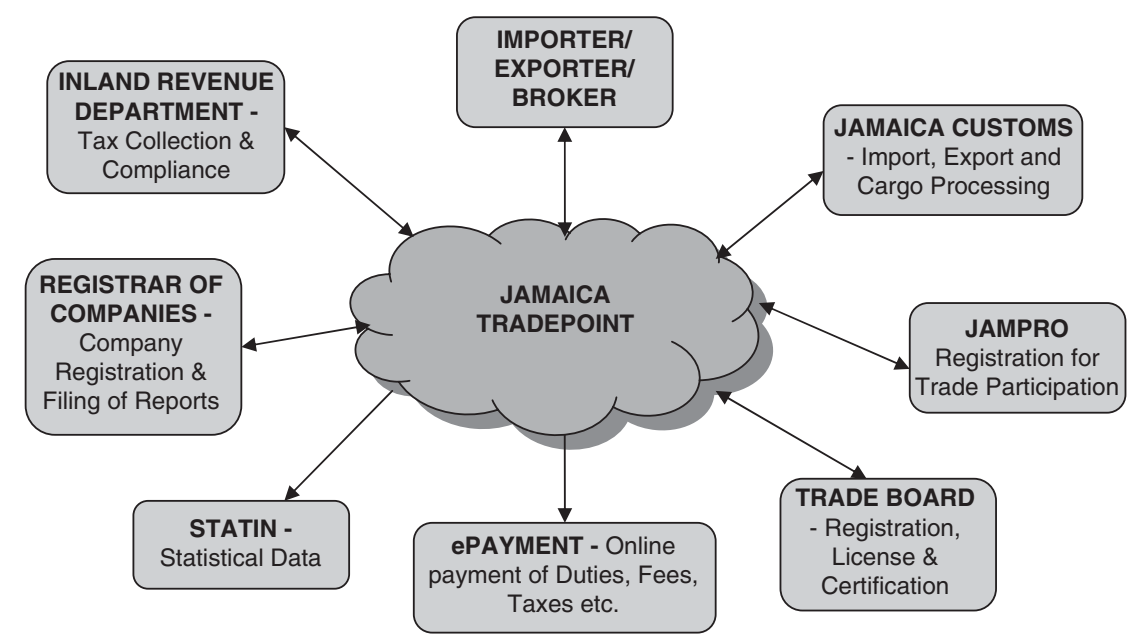

Figure 1 e-government services supporting international trade. 
the institution, or requiring conformance with other standards that essentially mandates the use of particular products or processes. The GOJ initiative that most exemplifies the use of standard setting to aid diffusion, is the use of electronic data interchange technology between the Jamaica Customs Department and Customs Brokers. The project known as CASE was first introduced in 1997. In the findings that follow the aim is to trace the trajectory of this Government policy initiative from 1997 to 2010 and to note the outcome. Although standard setting was a core rationale within this GOJ initiative, other institutional factors emerge and are discussed in the later analysis.

Pre-1997 the Jamaica Customs Department's responsibilities included facilitating the importation of goods into the island and the collection of government revenue at the points of entry. The processing of imports had been primarily manual, with a paper-based system at its core. The system involved shuffling large amounts of paper through many sections, most of the time using the Customs Brokers as the carrier. There was an inability to reconcile cash collected with the entries processed. This led to fraud, inconsistencies and an absence of accountability. Some individual customs brokers were experimenting with ICT but there was no widespread practice.

In 1997 to combat the above the Ministry of Finance and Planning (MoFP) launched the CASE system with manual and some electronic features. A voluntary system, it focused on imports and involved brokers completing electronic customs entries or forms and then physically transporting the information via floppy disks to the Customs Department to be uploaded onto their system. The aim of the system was to decrease processing time and increase efficiency in the Customs Department. The vision of utilising the Internet and incorporating e-payments at that time was non-existent. The usage rate was very low, with brokers shying away from using the system since the perceived benefits to them were limited. Additionally, poor communications infrastructure meant that dial-up lines frequently could not connect.

In 2002 in the context of the World Bank funded Public Sector Modernisation Project, Jamaica's first national ICT plan (2002) and further financial support from the InterAmerican Development Bank CASE was re-launched by FSL. The importance of trade facilitation via the Internet had been championed by Paulwell the Minister of Commerce, Science and Technology and became a strategic imperative.

The challenge in the information era is to increase competitiveness and increase international trade by providing electronic access to import/export/customs information, ... to develop a system of standardised trade. (GOJ, 2002, p. 16)

While developing the customs back-end entry processing system was a challenge, the real difficulty was the development of an application that would reside on the importer's computer and capture, validate and submit the customs entry electronically. This new system, called the C78 Electronic Entry Lodgement System, was introduced as the standard, with the expectation, later to become a requirement, that brokers adapt their procedures to use the new system. Initially resistance by brokers was strong. For many it required new technology and training and was perceived as expensive. It was also felt by many brokers that the manual system allowed them to differentiate their service levels and achieve advantage. A broker in summarising his view caught the mood of many of his colleagues:

Then (in 2003) we were not against technical innovation but this was risky and expensive. Simply trading was difficult enough ... training people on new government systems was something we couldn't do ... what were the benefits for us brokers? (BrokerCo \#1)

In 2003 to reinforce and accelerate usage of CASE technical support and training teams were created by FSL to work with brokers. These initiatives largely funded under the New Economy Project, together with the communications infrastructure improvements, resulted in a steady increase in the number of brokers adopting.

In 2004 CASE was implemented to a Web platform as part of the broader trade facilitation model (comprising trade facilitation; transport; banking and insurance; business information). Known as the JTP portal, it was a coordinated model and aimed to make trading seamless. Further adoption by the broker community was rapid as knowledge of the system spread. Even though it was a now a standard requirement many brokers went beyond this to innovate as the Managing Director of a small broking firm emphasised:

Although there was no immediate intention in 2004 for us to have a website, or engage further in ebusiness activities, using the JTP portal made us think how we could use other Internet based technology in the business for our benefit. We now routinely access real-time and archival data to provide additional services to our clients. (BrokerCo \#2)

By 2005 FSL reported 100\% compliance. For many brokers the reality had gone beyond compliance to self interest - a sense of ownership of the adoption process emerged. The system now known as iCASE covered imports (C78, now the C87 system) and was extended to exports (C82). In 2006-2009 extensive development and increased functionality has been added. FSL summarised the outcome:

Further enhancement to the electronic customs service was brought about by the implementation of the e-Payment system. The benefits include: increased revenue collection; ease and speed of entries, $24 \mathrm{~h}$, 7days per week availability for entry lodgement and payment reconciliation. (FSL, 2010)

In 2010 a total community of 42 corporate broking firms and 138 individual brokers are registered users. The next stage awaits the appropriate legislation that makes digital signatures legally binding, avoiding the 
one manual stage still required. FSL will lead the expansion of online services (Government of Jamaica, 2009).

\section{Analysis and discussion}

In this section the findings from the two empirical strands relating to ICT policy, prioritisation and practice are brought together and analysed. Both strands were informed by the institutional intervention model (King et al., 1994). These authors argue that institutional intervention in IT innovation can be constructed at the intersection of the influence and regulatory powers of institutions and the ideologies of supply-push and demand-pull models of innovations' (King et al., 1994, p. 139). Their model takes the form of a framework which outlines six types of intervention action that institutions can perform in an influential or regulatory role to produce the supply (technology)-push or demand (need)-pull context for the actions to be effective. Table 1 is based on this framework and provides the basis for the discussion of the two empirical strands.

From the tabulation four main themes emerge from institutional factor analysis. Together they constitute the four areas that surfaced most frequently, were identified as important by the interviewees and were supported by the policy documentation. These are at the policy rather

Table 1 Institutional factors in Jamaica's ICT innovation for international trade (after King et al., 1994)

\begin{tabular}{lll}
\hline $\begin{array}{l}\text { Influence and regulatory } \\
\text { dimensions }\end{array}$ & $\begin{array}{l}\text { Empirical strand \#1 } \\
\text { Policies and priorities - national 5-year } \\
\text { strategic IT plan }\end{array}$ & $\begin{array}{l}\text { Empirical strand \#2 } \\
\text { e-government in practice: international trade - CASE }\end{array}$ \\
\hline Knowledge Building & $\begin{array}{l}\text { Knowledge building prioritised. National IT plan } \\
\text { informs educational plan. E-Learning project to }\end{array}$ Jovernments own agency FSL, in conjunction with \\
& $\begin{array}{l}\text { promote internet usage. Creation of agency - Fiscal } \\
\text { Services Ltd (FSL) - to develop national Customs Automated Services and the subsequent }\end{array}$ & $\begin{array}{l}\text { development and evolution. Accumulated experience } \\
\text { informs other e-Government international trade } \\
\text { competency in ICT planning and implementation. }\end{array}$
\end{tabular}

Knowledge Deployment Government views its own use of technology as crucial and aims to become a model user of technology. Explicit commitment to education and providing training to public and private sectors.

Subsidy

Standards

Innovation Directive

Mobilisation
Central to the Public Sector Modernisation Program (PSMP) with funding and technical assistance from multiple international agencies - e.g. World Bank, EU, Inter-American Development Bank. A total of 30 aid supported projects for PSMP.

New legislative and regulatory framework for the new economy practices, including Electronic Transactions Act and new agency for administering telecommunications industry and IPR.

National commitment to use ICT to create enabling environment for other economic sectors - policy and resource focus on: ICT infrastructure and access viewed as a precondition for delivery of other services; e-government; economic development, especially international trade; facilitating and promoting e-business.

New agency created - Central Information Technology Office - to coordinate national ICT plan and build partnerships between local and overseas public and private sector organisations.
CASE technical support and training teams created by FSL specifically for the broker communities - corporate and private - at zero or low cost. Broker sector benefits from broader educational improvements including internet skills.

The multi-international agency supported PSMP provides the context for the individual projects. CASE is directly supported by Inter-American Development Bank in an 8-year program of online services support. Training and systems implementation support is funded through PSMP and the New Economy Project in particular.

The shift from voluntary to required practice for brokers achieved through the CASE standards and the removal of manual options. Technical standards led by FSL from standard proprietary EDI to purpose built applications and Web platform hosted. Total broker compliance achieved over 3 years.

Rooted in the World Bank's view of the importance of ICT for transformational change in developing economies. In the PSMP the Government prioritised ministries and agencies that were revenue generating and facilitated international trade. The Customs Department was a prime candidate.

Awareness building within the broker and trade community for CASE. 
than firm level. Although located in the GOJ setting they potentially lead to an improved understanding and theory development for e-government in developing and transitional economies. In turn they cover the role of national plans, e-government priorities, resource dependency and finally the nature of government intervention. Each is discussed below with reference to the underlying institutional factors that contribute significantly to the theme.

\section{The significance of national plans}

Two institutional factors, Innovation Directive and Knowledge Building, combine to provide evidence of the role of national plans in e-government. The Jamaican experience is revealing. Firstly, the plan is a national IT plan, which is part of a wider national industrial policy including both technical and human infrastructure. It is the highest level statement of policy intent and equates to the Innovation Directive. Within this IT plan e-government is just one of four objectives, the others being infrastructure, economic development and e-business. All four of these areas are overlapping and are subsumed within the ICT strategy - ICT is the precondition for everything else. It explains the prioritisation of infrastructure policy and legislation. The primacy of this viewpoint was emphasised by a policy advisor:

Our national ICT plan which we formalised in 2002 can only be achieved by ensuring that all our short and longterm goals are geared towards firstly improving our telecommunications infrastructure ... then creating a strong legislative and regulatory framework for e-business and providing online government services ... Initiatives in partnerships with international support has been crucial. (Policy advisor \#1)

This is a developing country perspective, and contrasts with the underlying assumption in developed countries that connectivity is ubiquitous and bandwidth close to being a commodity. Secondly, the status of the ICT plan is cross-governmental. For example, the Ministry of Commerce Science and Technology was responsible for the plan but the Ministry of Education, Youth and Culture developed the eLearning program within the national ICT frame work. Other examples of cross ICT planning include the Ministry of Industry, Investment and Commerce linking with the MoFP. Finally, the importance of realising plans was recognised with the creation and strengthening of Fiscal Services Ltd as an agency for effective implementation - clear evidence of the Knowledge Building factor.

In terms of effectiveness independent measures suggest that a cohesive national plan for ICT has been beneficial to Jamaica. A GOJ policy advisor referred to the World Bank's unflattering view of Jamaica and how this has changed:

Jamaica has not lived up to its early promise ... Its close proximity to the United States of America, which is the largest consumer in the world, as well as an educated,
English-speaking workforce, places Jamaica in a potentially advantageous position ... The country's economic history is a story of paradoxes and potential. (Policy advisor \#2, referring to World Bank, 2004, p. 4)

By 2008 The UN Global E-government Readiness Index ranked the country 1 st in the Caribbean region and 59th in the world. The 2006/07 Information Technology Report ranked Jamaica 45th out of 122 countries in terms of networked readiness. Finally, the Economic Intelligence Unit ranked Jamaica 40th in the 2009 e-readiness assessment. All these measures reflect the benefit of planned infrastructure development, both technical and social, and are impressive for a small developing country with a population of 2.8 million.

\section{The setting of e-government priorities}

Here the two institutional factors of Innovation Directive and Subsidy signal the priorities. Clearly, for e-government to have an impact, either incremental or transformational, there must be diffusion and adoption of the relevant technology by both businesses and citizens. In Jamaica, evidence of this impact is more readily available in businesses rather than individuals. The Internet is less widely diffused in homes and many individuals still only have access through work or school. This highlights a second difference between developed and developing economies in relation to priorities. In Jamaica, from policy through to the allocation of resources, the overriding consideration for e-government is economic development. This was signalled earlier in the paper but was reinforced by a policy advisor:

The single portal (Jamaica Trade Point Portal) is the result of our coordinated model to provide trade facilitation via the Internet and is a priority for us ... it has great implications for the export sector, the majority of which are SMEs ... the possibility exists for capacity building and increased competitiveness for our portal users. In all of these initiatives the IDB (Inter-American Development Bank) assisted project was central to making progress. (Policy advisor \#3)

This focus on economic development as a strategic imperative is the principal theme in all the main institutional agencies (OECD, 2006; UNCTAD, 2006; World Bank, 2007a). The interconnectedness between Innovation Directive and Subsidy is a core characteristic of strategic ICT development in Jamaica and was further emphasised by the same policy advisor.

In our partnerships with the international banks etc. choices about priorities are part of the proposal process that we discuss with them - the single trade portal is a good example of a strong revenue raising activity that also helps us grow our trade based economy .... (Policy advisor \#3)

In this setting although the citizen is important there is recognition that connecting citizens, expanding e-democracy and better governance can only occur in the context of economic development. 
In contrast in developed countries the emphasis, reflected in the allocation of resource, has been on government agencies and the citizen with the aim of improved governance and service efficiencies (BeynonDavies \& Martin, 2004; Margetts, 2006; Bekkers \& Homburg, 2007; King \& Cotterill, 2007). Put another way in a developed economy the potential economic benefits while recognised as important become an emergent property, rather than a strategic imperative per se.

\section{Resource dependency}

The institutional factor of Subsidy underlines the dependency on external resources in a developing country context. In many ways this last insight is the most important and is completely under-researched. Developing economies are not in a position to resource the infrastructure and educational developments needed to network together citizens, businesses and government. Even modest national investments require external assistance from the international agencies and development banks (World Bank, 2007a). The GOJ is a strong example. Despite its relative wealth compared to other developing economies it has required a portfolio of technical and financial aid to implement its national industrial and ICT plans. This was highlighted by Minister of Technology:

\begin{abstract}
The main thrust for our e-government comes from the ICT project that we launched in 2002, jointly funded by the Government of Jamaica and the Inter-American Development Bank (IDB). This joint ICT project was initially planned to last for three years and was supplemented by an IDB loan of U.S.\$17 millions, but the project was rescaled and we extended the collaboration for five additional years. (Paulwell, 2005)
\end{abstract}

The consequence of such joint development programmes is that when determining priorities the views of the supporting agencies must be taken into account and explains in part the emphasis on e-government projects linked to economic growth. The JTP programme, which includes the CASE project, is a direct example. This project received priority, and external support, precisely because of its centrality to improving Jamaica's trading performance.

\section{The overall importance of government intervention}

This is strongly evidenced in all six institutional factors. In the example of CASE intervention by the government is both direct and indirect. Direct intervention occurs through priority setting, the use of its own agency FSL to implement CASE and the Government requirement for brokers to adhere to new customs standards. The pivotal role played by standards in the GOJ's plans for the trade portal was emphasised by a policy advisor.

The early work on a new automated customs service started 10 years ago but only a few bothered to use it ... When we moved to the re-launched C78 automated system we gave notice to the broker community that this would become the standard system and the only one available to them ... this is what happened and today compliance is total. (Policy advisor \#4)

In contrast indirect intervention is manifested in the infrastructure development, the use by Government of its own technology and the wider educational initiatives. Intervention in this way provides insight into the process for implementing the national ICT plan that is underway in Jamaica. The plan and its implementation are two sides of the same coin - each informs the other and the GOJ takes responsibility for both. This gives support to the relevance of King's et al. (1994) position on the role of government in developing economies to accelerate IT innovation. It is interesting to compare this with the Margetts (2006) and many other authors. Her paper opens with the contrast in the previous decade between the progress and self-sufficiency of the private sector in their use of the Internet, and that of the state in terms of e-government. It is an unstated assumption that in the main private enterprise will make its own way - the neoclassical philosophy of laissez-innover. In a developing country context, however, where economic development is prime, the international agencies see the role of government as a key responsibility.

\section{Conclusions}

This research sets out to trace the priorities and policies taken by the Jamaican Government to facilitate the development of e-government. The overarching theme is one of selective intervention (Altenburg \& Von Drachenfels, 2006) facilitated through financial and technical assistance.

In terms of theory the main interpretive frame used in the analysis is based on an institutional approach, and especially King et al. (1994). Firm-level considerations were excluded from their analysis. This is a limitation but not a criticism since no single theoretical frame can adequately deal with the juxtaposition of macro and micro level analyses. Firm-level factors are always important in understanding the behaviour of individual firms and the adoption of the customs automated systems by Jamaican brokers is no different. Some firms were early adopters; others were reluctant and needed support. Theories of adoption such as technology acceptance model (Davis, 1989), information systems success model (DeLone \& McLean, 1992) and institutional approach (DiMaggio \& Powell, 1983) provide the basis for the analysis of such different behaviours. In this research, however, all the firms were compliant - the emphasis was not on understanding individual firm narratives but rather at the policy level to better appreciate how the cohort of broker firms had responded to the Government's initiative. In terms of an institutional perspective this can be viewed as coercive isomorphism (DiMaggio \& Powell, 1983). 
From the analysis and discussion there are two main observations that contribute to theory and a third which reflects on practice.

Firstly, in relation to the King et al. push-pull institutional approach the research confirms the robustness of the approach in explaining and highlighting the role of government in the diffusion IT innovation. Although in their original work the focus was on technology innovation policy within the context of developed and newly industrialised countries the findings of this research suggest that the six factors originally identified adequately cover the situation for developing countries. Importantly, however, there are significant differences in the relative importance of these factors. In the Jamaican developing country context the three institutional factors of Innovation Directive, Standards and Subsidy, either singly or in combination, are prime and exerted the most influence on the four main themes identified by the policy makers as significant. The remaining three factors - Knowledge Building, Knowledge Deployment and Mobilisation - were significant but secondary in that they depended on the existence of the others to be operationalised. An example is Knowledge Deployment where the technical support and training teams for the CASE initiative directly benefitted from the funding support within the PSMP.

In terms of the potential for extending this finding to other developing countries the analysis is promising. The detail in this research linking policy to implementation, through the tracking of a major e-government initiative over six years, is at a level beyond the King et al. work and allows a judgement about the relative importance of institutional factors to be made. In future applications of the King et al. framework in a developing country context the recognition of primary and secondary institutional factors in the push-pull context would further strengthen the analysis.

Secondly, the emergence of the four themes of national plans, priority setting, resource dependency and government intervention underlines the importance of context in understanding the behaviour of firms in a developing country context. All four themes are not adequately recognised in the extant e-government literature, especially the significance of subsidy from third part resources. Together these themes interact and have implications for the diffusion of innovations and the adoption of new technologies. Rogers (1995), Davis (1989, 1992), Venkatesh et al. (2003) are examples of contributions in these two areas but in all cases the analysis is centred on the individual, organisational or market factors - the wider institutional setting is weak or largely missing. In a developing country context this is a significant omission. In such countries the governmental institutional context is too important to exclude from the individual/firm level analyses and suggests a revised model of e-government which explicitly recognises the context differences between developed and developing economies. A starting point for a revised model would be a framing of the context in terms of the four emergent themes, which together constitute an institutional setting, and a linkage from these into the firm-level implications. The boundary between the firm and the institutional setting is soft and changes to accommodate the complex perceptions and realities of ongoing operations.

Thirdly, and relating to practice, the e-government transformation debate is typically set within the frameworks of NPM, DPM and e-bureaucracy, and is citizencentric. A difficulty is that the extension of this debate from the developed into the developing economies is done by default with insufficient recognition of the key differences, a point made by Huang et al. (2002). This research seeks to address this and affirms the value to developing countries of selective intervention as a policy and in particular the importance of ICT infrastructure, priority setting and subsidy. The latter is especially important in terms of the prioritisation of e-government towards economically significant initiatives. In terms of outcomes the direct and indirect interventions of the Government have delivered clear benefits. This was not inevitable, however, as both Heeks (2002) and Avgerou \& Walsham (2001) have pointed out. It suggests that the GOJ's plans, and particularly their implementation, were effective with potentially important lessons for other developing countries.

\section{Acknowledgements}

The authors would like to express their thanks to the Jamaican Government, Association of Commonwealth Universities and the British Council for funding this research. Thanks also to all the participants from government institutions and organisations who gave their time and valuable information. Special thanks to the Ministry of Commerce, Science and Technology, including Michael DuQuesnay, for facilitating access and encouraging independent research. The authors also wish to acknowledge the constructive suggestions of the three reviewers and of the editors in the drafting of this paper.

\section{About the authors}

David Brown is Chair of Strategy and Information Systems and Director of the China Management Centre at Lancaster University Management School, U.K. His research interests have two separate but linked strands. Firstly, strategic studies including strategic information systems, and secondly, the application of these strands 
internationally, including developing economies. The majority of his work is strongly organisationally based, including SMEs and has been published widely.

Sheryl Thompson holds first class degrees in Computing at undergraduate and post graduate levels from the
University of West Indies and University of Cambridge. She completed her Ph.D. in the Department of Management Science at Lancaster University in 2007 as a Commonwealth Scholar. Before her present post as lecturer in the University of West Indies she worked as an IT professional in industry and government for 6 years.

\section{References}

AltenburG T and VON Drachenfels C (2006) The new minimalist approach to private sector development: a critical assessment. Development Policy Review 24(4), 387-411.

AVGEROU C (2000) IT and organisational change: an institutionalist perspective. Information Technology and People 13(4), 234-242.

Avgerou C, Ciborra C, Cordella A, Kallinikos J and SMith M (2005) The Role of Information Communication Technology in Building Trust in Governance: Towards Effectiveness and Results. Inter-American Development Bank, Washington, DC. [WWW document] http://wwW .Ise.ac.uk/collections/informationSystems/research/researchProjects/ roleOfICT.htm (accessed 4 September 2008).

Avgerou C and WALSHAM G. (Eds) (2001) Information Technology in Context. Ashgate, Brookfield, VT.

BANERJEE P and CHAU P (2004) An evaluative framework for analyzing e-government convergence capability in developing countries. Electronic Government, an International Journal 1(1), 29-48.

BARCA C and CORDELLA A (2006) Seconds out, round two: contextualising e-government projects within their institutional milieu - a London authority case study. Scandinavian Journal of Information Systems 18(1), 37-60.

BASKERVILLE R and PRIES-Heje J (2003) Diversity in modelling diffusion of information technology. The Journal of Technology Transfer 28(2-3), 251-264.

BEKKERS V and HOMBURG V (2007) The myths of e-government: looking beyond the assumptions of a new and better government. The Information Society 23, 373-382.

BELLAMY C and TAYLOR J (1998) Governing in the Information Age. Oxford University Press, Buckingham.

BEYNON-DAVIES P and MARTIN S (2004) Electronic government and the modernisation agenda: progress and prospects for public service improvement. Local Government Studies 30(2), 214-229.

BROWN DH and LOCKETT N (2004) Potential of critical e-applications for engaging SMEs in e-business: a provider perspective. European Journal of Information Systems 13, 21-34.

BUI TX, SANKARAN S and SEBASTION IM (2003) A frame work for measuring national e-readiness. International Journal of Electronic Business 1(1), 3-22.

CENTRE fOR DEMOCRACY AND TECHNOLOGy (2002) The e-Government Handbook for Developing Countries. World Bank Institute, Washington.

CHECKLAND PB and POULTER J (2006) Learning for Action: A Short Definitive Account of Soft Systems Methodology and Its Use for Practitioners, Teachers and Students. John Wiley, Chichester.

CHEN Y, CHEN H, HUANG W and CHING R (2006) E-government strategies in developed and developing countries: an implementation framework and case study. Journal of Global Information Management 14(1), 23-26.

CORDELLA A (2007) E-government: towards the e-bureaucratic form? Journal of Information Technology 22(3), 265-274.

DAMSGUARARD J and LYYTINEN K (1996) Government strategies to promote the diffusion of electronic data interchange: what we know and what we don't know. Information Infrastructure and Policy 5, 169-190.

DAVIS F (1989) Perceived usefulness, perceived ease of $U$. and user acceptance of information technology. MIS Quarterly 13(3), 319-328.

DAVIS G (1992) A model for the adoption and diffusion of information systems in less developed countries. In The Global Issues of Information Technology Management (PAVLIA S, PAVLIA P and ZIGLI R, Eds), IDEA Group Publishing, Hershey, PA.

DELONE W and MCLEAN E (1992) The Delone and McLean model of information systems success: a ten-year update. Journal of Management Information Systems 19(4), 9-30.

DHILLON GS, WEERAKKODY V and DWIVEDI YK (2008) Realising transformational stage e-government: a UK local authority perspective. Electronic Government, an International Journal 5(2), 162-180.

DIMAGGIO P and POWELL W (1983) The iron cage revisited: institutional isomorphism and collective rationality in organisational fields. American Sociological Review 48, 147-160.

ECONOMIC INTELLIGENCE UNIT (EIU) (2005) The 2005 E-readiness Rankings. The Economist Intelligence Unit, London.

ECONOMIC INTELLIGENCE UNIT (EIU) (2009) E-readiness Rankings 2009: The Usage Imperative. The Economist Intelligence Unit. [WWW document] http://www-935.ibm.com/services/us/gbs/bus/pdf/e-readiness_rankings_ june_2009_final_web.pdf.

FLYVBERG B (2006) Five misunderstandings about case study research. Qualitative Inquiry 12, 219-244.

FOUNTAIN J (2001) The paradoxes of public sector customer service. Governance 14(1), 55-73.

FRIEDLAND R and ALFORD R (1991) Bringing society back in: symbols, practices, and institutional contradictions. In The New Institutionalism in Organizational Analysis (DIMAcGIO P and POWELL W, Eds), pp 232263, University of Chicago Press, Chicago, IL.

FSL (2010) Customs automated systems. [WWW document] http:// www.fsl.org.jm/systems/ (accessed 16 September 2010).

GibBS J, KRAEMER K and Dedrick J (2002) Environment and Policy Factors shaping E-commerce Diffusion: A Cross-Country Comparison. Centre for Research on Information technology and Organisations. University of California, Irvine.

GILBERT AL (1992) A transaction costs model of international information technology transfers: the dynamics of intelligence and control. In The Global Issues of Information Technology Management (PALVIA S, PALVIA P and ZIGLI R, Eds), pp 403-426, IDEA Group Publishing, Hershey, PA.

GOVERNMENT OF JAMAICA (2002) Five-year strategic information technology plan for Jamaica. [WWW document] http://www.mct.gov.jm/ (accessed 6 September 2008).

GOVERNMENT OF JAMAICA (2003) Electronic commerce (transaction) policy. [WWW document] http://www.mct.gov.jm/ (accessed 12 February 2005).

GOVERNMENT OF JAMAICA (2006) Transformation of the ICT sector: overview of ICT development in Jamaica. [WWW document] www.mct.gov.jm/transformationoftheicsector2.pdf (accessed 7 September 2008).

GOVERNMENT OF JAMAICA (2009) Strategic project plan for the restructuring of the public sector 2009-2011. [WWW document] http://www .mct.gov.jm/.

HANNA N (2003) Why national strategies are needed for ICT-enabled development. World Bank Staff Working Paper, Washington, DC.

HEEKS R (1999) Reinventing government in the information age. In Reinventing Government in the Information Age: International Practice in IT-enabled Public Sector Reform (HEEKS R, Ed.), pp 9-21, Routledge, London.

HEEKS R (2002) Information systems and developing countries: failure, success, and local improvisations. The Information Society 18, 101-112.

HENRIKSEN HZ and ANDERSEN KV (2004) Diffusion of e-commerce in Denmark: an analysis of institutional intervention. Knowledge, Technology \& Policy 17(2), 63-81.

HUANG W, D'AMBRA J and BHALLA V (2002) An empirical investigation of the adoption of egovernment in Australian citizens: some unexpected research findings. Journal of Computer Information Systems 43(1), $15-22$. 
IRANI Z, LOVE P and JONES S (2008) Learning lessons from evaluating eGovernment: reflective case experiences that support transformational government. Journal of Strategic Information Systems 17, 155-164.

KALLINIKOS I (2006) The Consequences of Information: Institutiona Implications of Technological Change. Edward Elgar, Cheltenham, UK.

KING IL, GuRbanaxani V, KRaemer KL, MCFarlan FW, Raman KS and Yap CS (1994) Institutional factors in information technology innovation. Information Systems Research 5(2), 139-169.

KING JL and KRAEMER KL (1995) Information infrastructure, national policy, and global competitiveness. Information Infrastructure and Policy 4(1), $5-28$.

KING S and COTTERILL S (2007) Transformational government? The role of information technology in delivering citizen-centric local public services. Local Government Studies 33(June), 333-354.

KOVACIC ZJ (2005) A brave new e-world? An exploratory analysis of worldwide e-government readiness. International Journal of Electronic Government 1(3), 15-32.

LANE J (1997) Public sector reform: only deregulation, privatisation and marketisation? In Public Sector Reform: Rational, Trends and Problems (LANE J, Ed.), pp 1-16, Sage Publications, London.

MARGETTS H (2006) E-government in Britain - a decade on. Parliamentary Affairs 59(2), 250-265.

MASON J (2002) Qualitative Researching, 2nd edn, Sage, London.

MAXWELL J (1996) Qualitative Research Design. Sage, California.

MEYER J and ROWAN B (1977) Institutionalised organizations: formal structure as myth and ceremony. American Journal of Sociology $\mathbf{8 3}$ 340-363.

MINISTER FOR CABINET OFFICE (2005) Transformational Government-Enabled by Technology. Cabinet Office, London.

MONTONTEALEGRE R (1999) A temporal model of institutional interventions for information technology adoption in less-developed countries. Journal of Management Information Systems 16(1), 207-232.

NORRIS DF and MOON MJ (2005) Advancing e-government at the grassroots: tortoise or hare? Public Administration Review 65(1), 64-75.

O'DONNELL O, BOYLE R and TIMONEN V (2003) Transformational aspects of e-Government in Ireland: issues to be addressed. Electronic Journal of e-Government 1(1), 23-32. [WWW document] http://ejeg.com/ volume-1/volume1-issue-1/issue1-art4-odonnell-boyule-timonen.pdf.

ODERA M and MADON S (1993) Information Technology Policies and Applications in the Commonwealth Developing Countries. Commonwealth Secretariat, London.

ORGANISATION FOR ECONOMIC COOPERATION AND DEVELOPMENT (2003) Making Life Easy for Citizens and Businesses in Portugal: Administrative Simplification and e-Government. OECD, Paris.

Organisation fOR ECONOMIC COOPERATION AND DEVELOPMENT (2004) The e-Government Imperative. OECD, Paris.

ORGANISATION FOR ECONOMIC COOPERATION AND DEVELOPMENT (2005) Commerce and Development Report. OECD, Paris.

ORGANISATION FOR ECONOMIC COOPERATION AND DEVELOPMENT (2006) Efforts and Policies of the Members of the Development Assistance Committee. OECD, Paris.

ORGANISATION FOR ECONOMIC COOPERATION AND DEVELOPMENT (2008) e-Government Studies: Finland. OECD, Paris.
PAULWell P (2005) Sectoral Budget Presentation 2005/2006. Ministry of Commerce, Science \& Technology (with Energy), Kingston.

PLANNING INSTITUTE OF JAMAICA (PIOJ) $(2005,2006)$ Economic update and outlook. [WWW document] wWw.pioj.gov.jm (accessed 7 January 2009).

RAHMAN R (2007) E-government readiness: from the design table to the grass roots. ACM International Conference Proceedings Series 232 (archive), 225-232.

ROGERS EM (1983) Diffusion of Innovations. Free Press, New York.

ROGERS EM (1995) Diffusion of Innovations. Free Press, New York.

SCHWARE R and DEANE A (2003) Deploying e-government programs: the strategic importance of ' $\mathrm{I}$ ' before ' $\mathrm{E}$ '. Info 5(4), 10-19.

ScOTT J (1990) A Matter of Record. Polity, Cambridge.

SELZNICK P (1957) Leadership in Administration, A Sociological Interpretation. Harper \& Row, New York.

SILVERMAN D (2005) Doing Qualitative Research, 2nd edn, Sage, London.

UNITED NATIONS CONFERENCE ON TRADE AND DEVELOPMENT (UNCTAD) (2005) The Digital Divide Report: ICT Diffusion Index 2005. United Nations, New York and Geneva.

UNITED NATIONS CONFERENCE ON TRADE AND DEVELOPMENT (UNCTAD) (2006) Information Economy Report: The Development Perspective. United Nations, New York and Geneva.

United Nations Public Administration Network (UNPAN) (2003) Global E-Government Survey: E-government at the Cross Roads. United Nations, New York.

United Nations Public Administration Network (UNPAN) (2004) Global E-Government Readiness Report: Towards access for Opportunity. United Nations, New York.

United Nations Public AdMinistration Network (UNPAN) (2005) Global E-Government Readiness Report: From E-Government to E-Inclusion. United Nations, New York.

United Nations Public Administration Network (UNPAN) (2008) Global E-Government Survey 2008: From E-Government to Connected Governance. United Nations, New York.

VENKATESH V, MORRIS M, DAVIS G and DAVIS F (2003) User acceptance of information technology: towards a unified view. MIS Quarterly 27(3), 425-438.

WEST DM (2004) E-government and transformation of service delivery and citizen attitudes. Public Administration Review 64(1), 15-27.

WORLD BANK (2001) Bridging the digital divide in the Americas. [WWW document] www.worldbank.com (accessed 10 January 2009).

WORLD BANK (2004) Jamaica: The Road to Sustained Growth, World Bank Country Study, World Bank, Washington.

WORLD BANK (2005) World development report: a better investment climate for everyone. [WWW document] http://siteresources.worldbank.org/INTWDR2005/Resources/complete_report.pdf.

WORLD BANK (2007a) Definition of e-government. [WWW document] http://go.worldbank.org/M1JHEOZZ280.

WORLD BANK (2007b) World development report 2007: development and the next generation. [WWW document] http://web.worldbank.org/ WBSITE/EXTERNAL/EXTDEC/EXTRESEARCH/EXTWDRS/EXTWDR2007/0.

WSIS (2005) Tunis agenda for the information society. [WWW document] http://www.itu.int/wsis/docs2/tunis/off/6rev1.html (accessed 12 January 2009).

YIN RK (2003) Case Study research: Design and Methods, 3rd edn, Sage Publications, Thousand Oaks, CA. 